Personalidade Acadêmica Homenageada:

Augustus B. Cochran III (Agnes Scott College)

\title{
ABSORVENTE DA DIGNIDADE: VIOLAÇÃO DE DIREITOS E OS CUIDADOS ÍNTIMOS E O ACESSO À SAÚDE DA POPULAÇÃO PRISIONAL FEMININA
}

\section{ABSORBING DIGNITY: VIOLATION OF RIGHTS AND INTIMATE CARE AND ACCESS TO HEALTH OF THE FEMALE PRISON POPULATION}

\section{RAFAELA CARVALHO COUTINHO OLIVEIRA} Graduanda em Direito, modalidade integral, pela Escola Superior Dom Helder Câmara. Belo Horizonte-MG. E-mail: rafacouttinho@outlook.com.

\section{CAIO AUGUSTO SOUZA LARA} Mestre e Doutor em Direito pela Faculdade de Direito da Universidade Federal de Minas Gerais - UFMG. Professor da Escola Superior Dom Helder Câmara. Pesquisador Associado ao Programa RECAJ-UFMG - Acesso à Justiça e Solução de Conflitos. Secretário de Comunicação do Conselho Nacional de Pesquisa e Pósgraduação em Direito - CONPEDI. Belo Horizonte-MG. E-mail: caiolarabh@yahoo.com.br.

\section{RESUMO}

O tema-problema da pesquisa que se pretende desenvolver é o descaso em relação as questões de higiene e de saúde das mulheres em situação prisional na sociedade brasileira. Diante dessa perspectiva, faz-se necessário ressaltar, inicialmente, o contingente de mulheres encarceradas no Brasil, que segundo o Departamento Penitenciário Nacional (Depen) do Ministério da Justiça, o país 


\section{Personalidade Acadêmica Homenageada:}

Augustus B. Cochran III (Agnes Scott College)

encontra-se na situação de quinta maior população de detentas do mundo. Além disso, o crescimento da população carcerária feminina ocorreu de forma brusca nos últimos 15 anos no país, representando quantitativamente $567 \%$ segundo dados do Conselho Nacional de Justiça (CNJ) publicados no ano de 2015, o que consequentemente reforça a necessidade de trazer a visibilidade para essa questão. Nesse contexto, apesar da Legislação da Saúde no Sistema Penitenciário sintetizar normativas para a garantia dos direitos da população carcerária, como retratado na Seção II da Lei de Execução Penal (LEP) referente a Assistência Material presente no artigo 12, que consta a assistência material ao preso e ao internado mediante ao fornecimento de alimentação, vestuário e instalações higiênicas, a efetividade de tais garantias diferem-se quando postas na realidade. Outrossim, o acesso as políticas sociais, sobretudo referentes a saúde distancia-se das políticas prisionais como se não equivalessem, a postura estatal diante dessas condições é de relativa negligência e da sociedade de caráter punitivo de pena, visto que não propõe de fato os direitos de reintegração para as pessoas em conflito com a lei, em especial para as mulheres. Apesar da Lei de Execução Penal (LEP) dedicar o artigo 14 presente na seção III da Assistência à Saúde do §3ำ que consiste em assegurar o acompanhamento médico à mulher, principalmente no prénatal e no pós-parto, extensivo ao recém-nascido, a juridicidade não é posta em prática. Desse modo, relata-se que questões particulares da realidade feminina, como o ciclo menstrual, o período de gestação e exames relativos à ginecologia são omitidos e acarretam consequências graves para as mulheres na condição de cumprimento de pena. Ademais, o problema objeto da investigação científica proposta é: quais são as implicações da falta de itens básicos de higiene e o acesso precário à saúde na qualidade de vida das mulheres em situação de cumprimento de pena? Assim, é levantada a hipótese de que acesso deficiente a itens básicos de higiene e o descaso com o amparo à saúde das mulheres em situação de encarceramento se dá de forma significativa, tendo em vista que os presídios são negligenciados por iniciativas estatais e há um descaso da própria sociedade no que se refere a essa realidade. O objetivo geral do trabalho é analisar as condições subumanas da mulher dentro do sistema prisional brasileiro, e de que forma os seus 


\section{Personalidade Acadêmica Homenageada:}

\section{Augustus B. Cochran III (Agnes Scott College)}

direitos básicos são feridos mediante ao descaso da sociedade e do Estado com essa parcela estigmatizada da população. A pesquisa que se propõe pertence à vertente metodológica jurídico-sociológica. No tocante ao tipo de investigação, o tipo jurídico-projetivo. O raciocínio desenvolvido na pesquisa será predominantemente dialético. De acordo com a técnica de análise de conteúdo, afirma-se que se trata de uma pesquisa teórica, o que será possível a partir da análise de conteúdo dos textos, doutrinas, normas e demais dados colhidos na pesquisa. A partir do exposto, conclui-se que a peculiaridade dos cuidados para com a mulher carcerária não vem sendo observada. A importância de adaptação da estrutura dos presídios para atendê-las é necessária, pois há a necessidade da existência de diferentes aparelhos, diferentes metodologias de consultas e diferentes especializações médicas. Existe ainda uma forte carência de profissionais capacitados e disponíveis para este tipo de cuidado especializado e o descaso estatal faz parte da realidade do sistema prisional feminino.

PALAVRA-CHAVE: Sistema prisional feminino; Saúde; Higiene; Direitos Humanos.

\section{REFERÊNCIAS}

ADICHIE, Chimamanda. Sejamos todos feministas. 1. ed. São Paulo: Companhia das Letras, 2015.

BRASIL. Constituição da República Federativa do Brasil de 1988. Disponível em: http://www.planalto.gov.br/ccivil_03/constituicao/constituicao.htm. Acesso em: 11 mai. 2019.

$$
\text { Lei } \quad \mathbf{n}^{\circ} \quad \mathbf{7 2 1 0 / 1 9 8 4 .} \quad \text { Disponível }
$$
em: http://www.planalto.gov.br/ccivil_03/leis//7210.htm. Acesso em: 11 mai. 2019.

CANTÚ, Mariana Coelho; FRANÇA, Leandro Ayres. Condições, processo e experiência do encarceramento feminino: uma pesquisa de campo na penitenciária feminina do Paraná. Revista Jurídica - UNICURITIBA, Curitiba, v.1 n.38, p. 23 39, 2015.2 Disponível em: http://revista.unicuritiba.edu.br/index.php/RevJur/article/view/2071/1331. Acesso em: 21 mai. 2019. 
Personalidade Acadêmica Homenageada:

Augustus B. Cochran III (Agnes Scott College)

CERNEKA, Heidi. Homens que menstruam: considerações acerca do sistema prisional às especificidades da mulher. Veredas do Direito, Belo Horizonte, 21 set. de $2009 . \quad$ Disponível em: http://www.domhelder.edu.br/revista/index.php/veredas/article/view/6. Acesso em: 11 mai. 2019

FERNANDES, Waleiska. População carcerária feminina aumentou 567\% em 15 anos no Brasil. CNJ NOTíCIAS. Disponível em: http://www.cnj.jus.br/noticias/cnj/80853-populacao-carceraria-femininaaumentou-567-em-15-anos-no-brasil. Acesso em: 11 mai. 2019.

GUSTIN, Miracy Barbosa de Sousa; DIAS, Maria Tereza Fonseca. (Re)pensando a Pesquisa Jurídica. 4. ed. Belo Horizonte: Del Rey, 2015.

QUEIROZ, Nana. Presos que menstruam. 1a. ed. Rio de Janeiro: Record, 2015.

VARELLA, Drauzio. Prisioneiras. 1a․ ed. São Paulo: Companhia das Letras, 2017.

WITKER, Jorge. Como elaborar una tesis en derecho: pautas metodológicas y técnicas para el estudiante o investigador del derecho. Madrid: Civitas, 1985 